\title{
T. S. Eliot’s Ekphrastic Poems
}

\author{
Rosanna Rion \\ English Department, University of Barcelona, Barcelona, Spain \\ Email:rrion@ub.edu
}

Received November 21 $1^{\text {st }}$ 2013; revised December $23^{\text {rd }}$, 2013; accepted January $10^{\text {th }}, 2014$

\begin{abstract}
Copyright (C 2014 Rosanna Rion. This is an open access article distributed under the Creative Commons Attribution License, which permits unrestricted use, distribution, and reproduction in any medium, provided the original work is properly cited. In accordance of the Creative Commons Attribution License all Copyrights (C) 2014 are reserved for SCIRP and the owner of the intellectual property Rosanna Rion. All Copyright $(2014$ are guarded by law and by SCIRP as a guardian.
\end{abstract}

Poems which have been inspired by paintings or mention a pictorial work can be analysed following a long tradition of studies between painting and poetry. Three of Eliot's early poems: The Love Song of Saint Sebastian, Mr. Eliot's Sunday Morning Service and On a Portrait are examples of this kind of ekphrastic exercise. There are different kinds of connections between painting and poetry and Eliot uses the iconological elements for different aims. The painters who interested the poet shared in common the fact that they represent a bridge between past and future, not a moment of perfect execution but one of great creativities.

Keywords: Ekphrasis; Italian Primitives; Mantegna; Manet; Saint Sebastian

\section{Introduction}

In the studies on the connections between word and image we can find a long theoretical tradition that focuses its attention on the dialogues between painting and poetry. The word "ekphrasis" describes a poetic genre which proposes as reference, thematic base or topic for reflection a pictorial work. There have been many poets who have felt fascinated by painting, because poets, as any other creator, widen their fields of interest on every art and every sphere of life. This tradition begins with Horace, who in his Epistola ad Pisones uses the comparison between both arts as example:

Vt pictura poesis; erit quae, si propius stes, te capiat magis, et quaedam, si longius abstes;

haec amat obscurum, uolet haec sub luce uideri,

iudicis argutum quae non formidat acumen;

haec placuit semel, haec deciens repetita placebit ${ }^{1}$.

The Renaissance artists will take this quotation much further than, in principle, one would expect and will connect painting and poetry through thematic links, because painting will nourish from literature, with the creation of allegorical paintings and using myths as a source of inspiration. The narrative aim in these kinds of paintings will lead to the transposition of literary norms to the plastic arts. This idea persisted until 1766, when Lessing published his Laocoonte, where he distinguished the limits and differences between both arts. According to Lessing, while poetry integrated temporality, the plastic arts, anchored in spatiality, can only convey a moment "pregnant" of meaning which can refer to a story, but which is not comparable to a

\footnotetext{
${ }^{1}$ As is painting, so is poetry: some pieces will strike you more if you stand near, and some, if you are at a greater distance: one loves the dark another, which is not afraid of the critic's subtle judgment, chooses to be seen in the light; the one has pleased once the other will give pleasure if ten times repeated.
}

narrative.

Painting and poetry have expanded the possible ways of connection. An ekphrastic poem can just describe a painting, but it can also take a part of the visual references as a shared topic or reflect on the painter's life or the relation of the painter with his work.

T. S. Eliot was interested in painting since his academic years in Harward, where he attended a course on Florentine painting taught by Professor Edward Waldo Forbes and a course on history of ancient art by George Henry Chase. During his stay in Paris, as a student, the city was under constant artistic activity. In 1914, Eliot travelled through Italy and Germany, where he visited museums and admired works of art which made a great impact on him. Later on, his friendship with artists and critics such as Roger Fry and Wydham Lewis acquainted him with the aesthetic theories of his time as regards to plastic arts and particularly painting.

Some of Eliot's poems have connections with pictorial works and they are the ones which this essay will focus on. The aim of this analysis is to determine the connections between three of Eliot's early poems and some paintings; the poems are: The Love Song of Saint Sebastian, Mr. Eliot's Sunday Morning Service and On a Portrait. This essay wants to show, as well, Eliot's opinions on some works of art and some artists. Although the paintings referred to are by different authors, they share some aesthetic characteristics.

\section{Verbal Language and Visual Language}

Form and content are inextricable. There is no use of language purely ornamental and therefore style communicates ideology and the material through which we express ourselves is part of the message. Although it is possible to notice that a visual work and a text can share a referent, we cannot say that there is a sort of translation from one media to another, because 
every production has its own laws and limits.

Theoretic tradition on linguistic analysis has offered varied and productive tools to interpret literary texts, while reflection on the visual field has encountered more difficulties. Iconological studies have traditionally focussed their attention on thematic aspects and have provided us with critical texts of great erudition and beauty, as we can see, for example, in the classical work of Erwin Panofsky (take as an example his study of the evolution of Cupido's image following different literary trends and changes in the idea of love in the course of time in Studies on iconology, 1939) which set the basis for other scholars. In recent times a new approach has proved successful in the analysis of some abstract paintings: the apophatic aesthetics. The tradition of European mysticism has provided us with the idea of the negative hermeneutics, or the experience of the sacred deprived of any image, which finds its expression in the apophatic aesthetics: In what measure the languages of negativity have contributed in the twentieth century to a greater comprehension of the experience of nothingness, which has appeared with modern nihilism, and to what extent it has become an imperious need in the field of the arts is something which can only be accounted for by a morphology of those languages. The massive presence of negativity in the discourses is due, mainly, to the growing experience of nihilism [...]. Twentieth century poetry has contributed to the understanding of the experience of nothingness as the fundamental experience of our time which spiritual indigence shows, paradoxically, a symbolic and sacramental capacity of hosting mystery which had been exclusive of religious discourses (Vega, 2005: p. 49). In the case of Eliot, The Waste Land (1922) is a good example of this apophatic aesthetics; following the biblical tradition for the lament for lost cities, it becomes, as the very end indicates with the words "Shantih, shantih, shanty", a prayer from the spiritual desert.

Today, most of the discourses on the connection between literature and image have to do with cinema, but here again, we find we have not got an appropriate theoretical apparatus. The idea of using the methodology of linguistic analysis for the visual field, the "linguistic imperialism” (Gilman, 1989), cannot cover the visual world in all its semantic density and its complexity. Cristian Metz (1981) was one of the first to admit that the expression "cinematographic language" was, in principle, metaphorical, and the when compared with natural language, the difference were as significant as the similarities, pointing to the fact that, unlike with languages, it is not possible to determine a minimal unit of expression in the visual world that would work satisfactorily.

The connections between word and image need their own categories. Basically, images can cooperate or interfere with the text, cooperate because we understand their intention as complementary and they can reinforce the textual meaning and, on the other hand, they can interfere because we can understand them as expressing something different from the text. We have to bear in mind, though, that complementation is never innocent and it acquires meanings of its own although, in general, it shares the same referent, while interference compels us to decipher added meanings. These two categories do not cover all the possible connections between word and image, as we can see for example that in visual poetry we can only achieve meaning by reading word and image together and that both parts do not have semantic coherence on their own.

The vision of a harmonious combination of word and image was not shared by Roland Barthes (1964) who made clear that words parasite images and can never reinforce them because, in the transit from one structure to another, there are always secondary meanings.

We find a relevant distinction when we analyze the process through which word an image acquire meaning. While the word is always an abstract generalisation, the image brings about meaning by a specific particularisation. Although they follow different paths, they both need a context in order to be understood. If images owe more to other images, that is, to an iconological tradition, than to nature and, according to phenomenology, we only perceive what we can identify, we need a pragmatic vision which we can use in as many relevant aspects as possible to understand both ways of communication.

Rhetorical devices can describe both means of expression, although there are always aspects other than pure formalism that will determine our perception and interpretation. This theory has had a long tradition and has been followed by Barthes (1970), Eco (1979) or Zunzunegui (1998). We should bear in mind, though, that we cannot assign a particular effect or intention to a specific rhetorical device, be it verbal or visual. The constant reinterpretations which visual and verbal expressions are subject to are due to the changes in historical and social contexts. T. S. Eliot thinks about this reinterpretation in connection with the function of criticism in each historical moment. Any artistic form tells us about its time, and it defines and is defined by aspects wider than those from their own field.

This essay will look into three of Eliot's early poems and will go into depth on the iconological references. Although the references have been acknowledged in the bibliography on the author, there is no reflection as to why he chose them and their significance. A complete iconological study of Eliot's poems is still to be written and the aim of this essay is to constitute a contribution towards that goal.

\section{The Love Song of Saint Sebastian}

This early poem written in 1914 was part of the notebook which Eliot sold to the New York lawyer John Quinn in 1922, with the explicit desire that it should remain unpublished. Eliot's interest in Saint Sebastian comes from the pictorial world as well as from religion. During his stay in Harvard, Eliot attended courses on the history of art and read religious and mystical texts which influenced him and his poetic production. The Hindi Bhagavad Gita or Ascent to Mount Carmel by Saint John of the Cross are works which Eliot used as quotations in some of his poems, like The Waste Land or Four Quartets, and which allowed the poet to express his hope in an ascetic attitude as well as his view on the cultural desolation which worried him so much.

Although 1927 was the year when Eliot became a member of the Anglican Church, it is during the time when he wrote The Love Song of Saint Sebastian when he began to think in depth about his religious beliefs. In the letters to his friend Aiken ${ }^{2}$ from 1914 (in one of the he sends the poem) we can witness the desperate way in which the poet expresses his spiritual doubts and it is also from them that we learn about the impact which the vision of several pictorial works from the $15^{\text {th }}$ century portraying Saint Sebastian made on him: one of them was by Mantegna (Ca d'Oro, Venice), another attributed to Antonello

${ }^{2}$ Correspondence Eliot-Aiken, quoted in L. Gordon, Eliot's Early Years 1977, p. 61. 
de Mesina (Bergamo), a third one by Hans Memling (Brussels). Eliot mentions the erotism of the works and comments that there is nothing homosexual about them.

The painting by Mantegna is the one that most scholars mention as the one which inspired Eliot's poem. In the poem the ekphrastic exercise is different from the usual descriptive poems.

\author{
The Love Song of St. Sebastian \\ I would come in a shirt of hair \\ I would come with a lamp in the night \\ And sit at the foot of your stair; \\ I would flog myself until I bled, \\ And after hour on hour of prayer \\ And torture and delight \\ Until my blood should ring the lamp \\ And glisten in the light; \\ I should arise your neophyte \\ And then put out the light \\ To follow where you lead, \\ To follow where your feet are white \\ In the darkness toward your bed \\ And where your gown is white \\ And against your gown your braided hair. \\ Then you would take me in \\ Because I was hideous in your sight \\ You would take me in without shame \\ Because I should be dead \\ And when the morning came \\ Between your breasts should lie my head. \\ I would come with a towel in my hand \\ And bend your head beneath my knees; \\ Your earls curl back in a certain way \\ Like no one's else in all the world. \\ When all the world shall melt in the sun, \\ Melt or freeze, \\ I shall remember how your ears were curled. \\ I should for a moment linger \\ And follow the curve with my finger \\ And your head beneath my knees- \\ I think that at last you would understand. \\ There would be nothing more to say. \\ You would love me because I should have strangled you \\ And because of my infamy; \\ And I should love you the more because I mangled you \\ And because you were no longer beautiful \\ To anyone but me.
}

In a letter to Paul Elmer More, Eliot writes: "I am one whom his sense of void tends to drive towards ascetism or sensuality" (apud Gordon, 1977: p. 62) and this mixture of ascesis and sensuality is, precisely, what we find expressed in the poem. The allegory of human and sensual love as a mirror of the divine love to his church or his people is here distorted by the pleasure for pain and the annihilation instinct. Saint John of the Cross, author well known by Eliot, warns about the dangers in the mystical path, about the deviations and illnesses of the soul, and the poet is living a time of search and doubt which corresponds with this context. On the other hand, the literary model of the idealized woman from the dolce stil novo, which Eliot admired, finds in this poem the opposite goal to the Florentine poetry and, instead of leading the soul to salvation, takes the poetic subject to degradation and destruction, in the way of a
Belle dame sans merci.

Child's interpretation of the poem (1997: p. 84), as of a poetical subject who flagellates himself in order to gain entrance into a woman's bed, sets the poem in the context of desire and possession to such an extent that the erotic intensity allows no possibility to transcend the sensual. Eliot's comments on Saint Sebastian's pictorial representations focus also in the physical beauty and the impact of pain coming from them. Dramatic quality is one of the values that scholars have acknowledged to Mantegna's Saint Sebastian, but criticism on the painter and his contemporaries experienced a great change at the time when the poem was written. The quatrocento painters were described as "the Italian primitive", and this name implied that the artist who appeared later were the ones who would overcome the technical and expressive limitations of those "primitive" ones. But art critics, such as Roger Fry, friend of Eliot, worked to give new value to the image of the painters from the quatrocento and to convey the revolutionary idea that art was not an evolutionary process of constant improvement, but that every movement responded according to their priorities, and those have not always been the virtuosity of perspective or the realism that later on was describes as the paradigm of perfection: "they [artists from the $15^{\text {th }}$ century] refused to accept facts as they came from nature, except to the extend in which they could be subject to the generalizing power of their art. Facts should be assimilated to form before being accepted in the system” (Fry, 1920: p. 152).

This historical change of perspective will lead, also, to back up in the theoretical field the ideas that Matisse or Picasso defended from their artistic production, such as the defence of African sculpture or other artistic forms described as primitive and undervalued as examples of aesthetic expressions of their own right. Regarding literary criticism it will be Eliot, precisely, the one who will propose a similar theory in the field of writing, as he expresses in “Tradition and Individual Talent” (1922) (apud Eliot, 1953: p. 21):

He must be aware that the mind of Europe- the mind of his own country-a mind which he learns in time to be much more important than his own private mind-is a mind which changes, and that this change is a development which abandons nothing en route, which does not superannuate either Shakespeare, or Homer, or the rock drawing of the Magdalenian draughtsmen. That this development, refinement perhaps, complication certainly, is not, from the point of view of the artist, any improvement.

Andrea Mantegna (1431-1506) is also called "the archaeological painter” because he was the first to include Roman archaeological elements as part of his pictorial landscapes. His interest in antiquity and his sense of history made him very interesting for Eliot, just as it did his meaning as a link between past and future. The Roman ruins in Mantegna's paintings are due to his interest in archaeology as well as to his intention to show the triumph of Christianity over paganism, triumph which was also Eliot's desire as he expressed in writings such as Christianity and Culture (1948). The painting in the Ca d'Oro (panel, $68 \times 30 \mathrm{~cm}$ ) with a figure in contrapposto, (one of the several which the artist painted on Saint Sebastian) has an inscription: Nihil nisi divinvm stabile est. Coetera fvmvs” (Nothing except the divine can be stable. The rest is smoke), which reminds us that human life and suffering are temporary and which we also find in the epigraph of the poem Burbank with a 
Baedeker: Bleistein with a Cigar. The change Saint Sebastian undergoes form the human to the divine takes place in a second according the Christian faith, but Eliot, influenced by Buddhism and with many religious doubts, mixes Greek mythology, Christianity, and Buddhism in the poem The Death of Saint Narcissus, written in 1014 and in which the iconological reference to Saint Sebastian is clearly identifiable:

\section{The Death of Sain Narcissus}

Come under the shadow of this gray rock-

Come in under the shadow of this gray rock,

And I will show you something different from either

Your shadow sprawling over the sand at daybreak, or

Your shadow leaping behind the fire against the red rock:

I will show you his bloody cloth and limbs

And the gray shadow on his lips.

He walked once between the sea and the high cliffs

When the wind made him aware of his limbs smoothly

passing each other

And of his arms crossed over his breast.

When he walked over the meadows

He was stifled and soothed by his own rhythm.

By the river

His eyes were aware of the pointed corners of his eyes

And his hands aware of the pointed tips of his fingers.

Struck down by such knowledge

He could not live men's ways, but became a dancer before

God.

If he walked in city streets

He seemed to tread on faces, convulsive thighs and knees.

So he came out under the rock.

First he was sure that he had been a tree,

Twisting its branches among each other

And tangling its roots among each other.

Then he knew that he had been a fish

With slippery white belly held tight in his own fingers,

Writhing in his own clutch, his ancient beauty

Caught fast in the pink tips of his new beauty.

Then he had been a young girl

Caught in the woods by a drunken old man

Knowing at the end the taste of his own whiteness,

The horror of his own smoothness,

And he felt drunken and old.

So he became a dancer to God,

Because his flesh was in love with the burning arrows

He danced on the hot sand

Until the arrows came.

As he embraced them his white skin surrendered itself

to the redness of blood, and satisfied him.

Now he is green, dry and stained

With the shadow in his mouth.

In the poem, Narcissus experiences Saint Sebastian's martyrdom and goes through different states of consciousness through a series of metamorphosis. The problem of identity, in fact, had interested Eliot since the time of this doctoral thesis in Harvard: Experience and the Objects of Knowledge in the Philolophy of F. H. Bradley.

Another poet who wrote an ekphrastic poem on Saint Sebastian is Rilke, and the comparison with Eliot's poem is going to provide evidence of how they both focussed on very different traits and followed opposite aesthetical aims.

\section{Sankt Sebastian}

Wie ein Liegender so steht er; ganz

hingehalten von dem großen Willen.

Weitentrückt wie Mütter, wenn sie stillen, und in sich gebunden wie ein Kranz.

Und die Pfeile kommen: jetzt und jetzt

und als sprängen sie aus seinen Lenden, eisern bebend mit den freien Enden.

Doch er lächelt dunkel, unverletzt.

Einmal nur wird seine Trauer groß, und die Augen liegen schmerzlich bloß, bis sie etwas leugnen, wie Geringes, und als liessen sie verächtlich los die Vernichter eines schönen Dinges ${ }^{3}$.

In Rilke's Saint Sebastian the description follows the iconology which has always been connected to the Saint. Both poems talk about beauty but, where Eliot sees only physical beauty, Rilke discovers also the beauty of sacrifice. In Eliot, passion destroys the poetical character and his object of desire in his attempt to attain complete possession. In Rilke the doubt which seized the poetical character has no strength in front of the religious conviction; nevertheless, it is there, deeply human, as Eliot himself sustains in the Grantile Review, 24, No3 (1962) when he says that the man who doubts takes the problem of his faith seriously (apud Gordon, 1977: p. 72).

Eliot's poem is so far from convention that the title "love song" is not justification sufficient for the deviations in which he entangles the character, and it could be interpreted as a blasphemy. But within the chaos and the religious search which Eliot was experiencing at the time, blasphemy is only another way of connection with the divine: "During his first years in London, Eliot wrote blasphemous poems, but he explained later on that genuine blasphemy springs from the partial belief of a mind in an unusual and peculiar state of spiritual illness. Blasphemy can even be a way to affirm faith” (Gordon, 1977: p. 71).

On the other hand, and in spite of connections, links and loans between poetry and philosophy, both discourses are radically different, and the poet's convictions and ideology do not represent the essence of his poetry. Eliot, in an article about Goethe (1955) in On Poets and Poetry, criticises professor Heller's theories because he wanted to generalize the philosophical mission of poetry and it is Rilke, precisely, the poet who Eliot uses to exemplify how inadequate that attitude is.

\section{Mr. Eliot's Sunday Morning Service}

Eliot's admiration for Dante's simplicity of style entails his aim of searching for a language which, in spite of the complexity of the moment of modernity that he lives and which poetry cannot but show, is not fascinated by words which turn poems into an elitist product. Nevertheless, in his poem Mr. Eliot's Sunday Morning Service (1918) we find a deliberately pompous vocabulary, which serves as criticism against theological lucu-

${ }^{3}$ (He stands like someone lying down,/propped up by his own huge will./Off somewhere else, like mothers when they nurse,/and bound in himself like a wreath./ And the arrows arrive: now, and now,/as if they sprang out of his thighs,/iron and trembling at the ends. And still/he smiles darkly, he's not hurt.//Just once a sadness suddenly looms large,/and his eyes grow naked with pain/until they deny something, not worth the trouble,/filling with scorn as they come to relinquish/ those who would kill a beautiful thing. 
brations.

The lexical game between fertility and sterility shows the uselessness of the religious discussions in which some doctors of the church have spent their efforts. For Eliot, there is a part of discourse which religious speculation has generated that has only had as an effect the fact that the common man feels further and further from the church. Sweeny, the character in the poem who represents the uneducated man, highlights an especially painful contrast because his personality (developed also in other poems) is completely brutal.

In the poem we find two pictorial references: a fresco form the Umbrian school about the Baptism of Christ and a scene from Purgatory. Both images may not correspond with any existing work, but we will look at different hypothesis which have been proposed.

\section{Mr. Eliot's Sunday Morning Service}

Look, look, master, here comes two religions caterpillars.

The Jew of Malta.

Polyphiloprogenitive

The sapient sutlers of the Lord

Drift across the window-panes.

In the beginning was the Word.

In the beginning was the Word.

Superfetation of [Greek text inserted here],

And at the mensual turn of time

Produced enervate Origen.

A painter of the Umbrian school

Designed upon a gesso ground

The nimbus of the Baptized God.

The wilderness is cracked and browned

But through the water pale and thin

Still shine the unoffending feet

And there above the painter set

The Father and the Paraclete.

.....

The sable presbyters approach

The avenue of penitence;

The young are red and pustular

Clutching piaculative pence.

Under the penitential gates

Sustained by staring Seraphim

Where the souls of the devout

Burn invisible and dim.

Along the garden-wall the bees

With hairy bellies pass between

The staminate and pistilate,

Blest office of the epicene.

Sweeney shifts from ham to ham

Stirring the water in his bath.

The masters of the subtle schools

Are controversial, polymath.

Mr. Eliot's Sunday Morning Service can be found in the Collected Poems and, therefore, has had more attention from scholars. One of the elements which has not been pointed out, though, is the strange adjective that qualifies Christ's feet in the poem: "unoffending", but the topic of representing feet in religious painting has its own tradition and has been cause of important discussions; let us remember Caravaggio's Saint Mathew and the Angel which was rejected by the priests from Saint Louis of the French in Rome because: "the saint, when crossing the legs, showed that big fat naked foot” (Marangoni,
1973: p. 54)

The Umbrian school developed its activity during the $15^{\text {th }}$ century and among the most renowned painters that belonged to it we can mention: Piero della Francesca, Luca Signorelli, Perugino or Pinturrichio. The workshop activity included collaborative paintings; very often between master and apprentice and, because of that, many paintings share authorship. Southam (1981), when he comments the poem, suggests that the quoted work could be the Baptism of Christ by Piero della Francesca, which Eliot could have seen in the National Gallery in London, but this painting does not correspond with the exact iconographical description that the poem offers: the painting in Piero della Francesca does not show the nimbus over Christ's head or the representation of God the Father. In my opinion, the Baptism by Perugino and Pinturrichio in the Sistine Chapel is a more plausible possibility. Also, is there any better place than the Vatican to talk about theological discussions? Because undoubtedly, the poem refers to a Catholic church.

Although now we can appreciate the vivid colours in the paintings, it was not until the period (1980-1994) that the Sistine Chapel was restored, and this fact seems to contribute to connect the poem and Perugino and Pinturrichio's painting as the description coincides with the deterioration described in the poem.

Another possible pictorial referent could be the Baptism of Christ by Verrochio (Uffizi, Florence), because the artists was Perugino's master and, undoubtedly, marked the style of the Umbrian school. In this work commissioned by the monks from San Salvi, Leonardo might have contributed, as he was an apprentice of Verrocchio at the time, painting one of the angels (the one kneeling). This painting could have attracted Eliot because of its connotations as turning point between two moments radically different in the history of art, as it means the beginning of the end of the Italian Primitive and their way of understanding art. Eliot was very critical about leonardo's work, desmitifying his aura of perfection and undermining its central place in tradition as paradigm of pictorial quality, as we read in "Hamlet and his Problems” 1919: “...probably more people have thought Hamlet a work of art because they found it interesting, than have found it interesting because it is a work of art. It is the "Mona Lisa" of literature".

The process through which the accepted criticism is put in question can be also found in other countries. Marcel Ducamp also attacked the Tuscan genius with an iconoclastic gesture when he painted a moustache to the "Mona Lisa", the more mysthified work by Leonardo.

But rather than determining whether Eliot refers to an existing painting or not, the more relevant fact that connects these lines to the pictorial world is the task of the poet to collaborate to put into value 15th century Italian painting. If Roger Fry, in his criticism, shows the validity and independence of the Quattrocento aesthetics, Eliot helps to this aim by including a pictorial school from the time as part of his poetic world.

Another painting the poem refers to is the entrance to the Purgatory and it has a referent in Dante's Divine Comedy. But, although the authorship or existence of the Baptism of Christ painting described in the poem is difficult to determine, in the case of the Door to the Purgatory it is less likely to be a real painting. However, the relevant point is the use Eliot makes of this iconographic reference, and in Mr. Eliot's Sunday Morning Service the ekphrastic exercise helps the poet to contribute to a decadent and melancholic atmosphere which fills the whole 
poem.

\section{On a Portrait}

Edouard Manet painted La femme au perroquet in 1866 and it was exhibited in the 1868 salon. The work received negative criticism by the art critics and was only defended by those who admired the painter and understood the modernity of his art and his respect for tradition; they were great minds of his time like Baudelaire, Mallarmè and Zola.

The model who posed for the painting was Victorine Mouren, who appears also in the two paintings by Manet which caused scandal: Déjeuner sur l'herbe and Olimpia. In these two cases criticism arose from the mixture of the imitation of the classics and the new way in which Manet translate them to modernity, but La femme au perroquet is attacked because of its lack of dramatic effect and lack of poetical quality and the attitude of indifference which the face of the model expresses.

Manet himself tried to explain his intentions: "it is sincerity what provides works with a what may seem a protestation, when the painter has only tried to express his impression. He didn't mean to demolish tradition or to create a new kind of painting. He has just wanted to be himself” (apud Orienti, 1982: p. 6).

The poem On a portrait is a classical ekphrastic exercise based on Manet's painting. What the poet feels attracted to is, precisely, that indolence which the painting expresses, and Eliot's poem focuses in the distance between the painting and the observer.

\section{On a Portrait}

Among a crowd of tenuous dreams, unknown

To us of restless brain and weary feet,

Forever hurrying, up and down the street,

She stands at evening in the room alone.

Not like a tranquil goddess carved of stone

But evanescent, as if one should meet

A pensive lamia in some wood-retreat,

An immaterial fancy of one's own.

No meditations glad or ominous

Disturb her lips, or move the slender hands;

Her dark eyes keep their secrets hid from us,

Beyond the circle of our thoughts she stands.

The parrot on the bar, a silent spy,

Regards her with a patient curious eye.

The poem was written in January 1909, when Manet was again put into question, this time by voices from the avantgarde who did not want to admit their debt to him and who felt uncomfortable about Manet's admiration for classics like Velázquez, El Greco or Goya. Here we find again a key figure in the transformation of the artistic trends, in the transition from one movement to another, who nourishes from the past and steps into the future, and who is more himself than others convinced of their originality.

Another artist who was suffering the attacks from the critics was the poet Swinburne, admired by Eliot (although not unconditionally, as can be observed in "Swinburne as a poet" 1920). Before the Mirror ia an ekphrastic poem that Swinburne wrote on the painting Symphony in White by Whistler, in which the poet asks himself the same questions as Eliot when trying to discover the thoughts of the lady represented and feels the impossibility to be in "the other's" place.

\section{Conclusion}

The pictorial references Eliot is interested in for the composition of his ekphrastic poems have an element in common: they belong to painters who represent a bridge between different artistic periods. That moment of change, of respect for the past and first steps towards something different, is similar to the one the poet lived through his work. A relevant aspect is the will to assert the value of painters who were either being reconsidered, like Mantegna, or had fallen into discredit because they annoyed the artists with rupturist ideas, like Manet. Both artists share with Eliot their respect and admiration for the past, Mantegna including Roman ruins his paintings and Manet openly expressing interest for Velázquez.

The connections between painting and poetry in Eliot's work have different intensities. While in On a Portrait we can appreciate a classical ekphrastic exercise where the description played a leading role, in The Love Song of Saint Sebastian the pictorial referent is not so close to the poem. In fact, it is in The Death of Saint Narcissus where the iconological elements attributed to Saint Sebastian can be found. On a Portrait, inspired in Lady with a Parrot by Manet, can be interpreted very differently if the iconological element is not taken into account; David Moody (1994: p. 18) connects the poem with the Gioconda and says that the poetical voice has the attitude on curiosity of the parrot, but this interpretation does not coincide with Eliot's critical point of view about Leonardo's work. Another scholar, Martin Scofield (1988: p. 41) sees the poem as a preraphaelite portrait, and states that the parrot represents the materiality as opposed to the lady, who represents spirituality. But, following Gordon's biography, who tells us about the attention Eliot paid to Manet's painting, we can understand the element of radical modernity in the lady's attitude of boredom and indifference.

\section{REFERENCES}

Barthes, R. (1964). "Rhetorique de l'image” Communications (pp. 40-51). Paris: Editions du Seuil.

Childs, D. (1997). T.S. Eliot, Mystic, Son and Lover. London: The Athlone Press.

Eco, U. (1979). A Theory of Semiotics. Indiana University Press.

Eliot, T. S. (2001). Inventos de la liebre de marzo (Bilingual ed.). Madrid: Visor.

Eliot, T. S. (1999) Sobre poetes y poesia. Barcelona: Columna.

Eliot, T. S. (1998). The Letters of T.S. Eliot (Valery Eliot, ed.). New York: Harcourt Brace Jovanovish.

Eliot, T. S. (1953). Selected Prose (John Hayward, ed.). London: Penguin.

Eliot, T. S. (1967) Christianity and Culture. London: Harcourt, Inc.

Fry, R. (1988). Visión y diseño. Barcelona: Paidós.

Gilman, E. B. (1989). Interart Studies and the "Imperialism of Language”. Poetics Today, 10, 3-29.

Gordon, L. (1977). Eliot's Early Years. Oxford University Press.

Lessing, G. E. (1990) Laocoonte. Madrid: Técnos.

Marangoni, M. (1973). Para saber mirar. Madrid: Espasa-Calpe.

Metz, C. (1981). “Cine y lenguaje”, Imagen y lenguajes. Barcelona: Signos.

Moody, D. (1994). Thomas Stearns Eliot Poet. Cambridge University Press.

Panofsky, E. (1972) Estudios sobre iconología. Madrid: Alianza Universidad.

Sautham, B. (1981). A Student's Guide to the Selected Poems of T.S. Eliot. London: Faber \& Faber.

Scofield, M. (1988). T.S. Eliot: The Poems. Cambridge University 


\section{R. RION}

Press

Vega, A. (2005). Arte y santidad. Cuatro lecciones de estética apofàtica. Pamplona: Universidad de Navarra.

Zunzunegui, S. (1998). Pensar la imagen. Madrid: Càtedra.

Butler, J. (1990). Gender Trouble. Feminism and the Subversion of Identity. New York and London: Routledge.
Draper, J. W. (1938). The Theory of the Comic in Eighteenth-Century England. Journal of English and Germanic Philology, 37, 207-23.

Savoy, E. (2007). "Entre chien et loup": Henry James, Queer Theory and the Biographical Imperative. In P. Rawlings (Ed.), Palgrave Advances in Henry James Studies (100-125). New York: Palgrave Macmillan. 